Article

\title{
The Effect of Ultraviolet Irradiation on the Physicochemical Properties of Poly(vinyl Chloride) Films Containing Organotin(IV) Complexes as Photostabilizers
}

\author{
Duaa Ghazi ${ }^{1}$, Gamal A. El-Hiti ${ }^{2, *(\mathbb{C})}$, Emad Yousif ${ }^{1, *(\mathbb{D})}$, Dina S. Ahmed ${ }^{3}$ and \\ Mohammad Hayal Alotaibi 4 \\ 1 Department of Chemistry, College of Science, Al-Nahrain University, Baghdad 64021, Iraq; \\ duaa.g934@gmail.com \\ 2 Cornea Research Chair, Department of Optometry, College of Applied Medical Sciences, \\ King Saud University, P.O. Box 10219, Riyadh 11433, Saudi Arabia \\ 3 Department of Chemistry, College of Science, Tikrit University, Tikrit 34001, Iraq; dinasaadi86@gmail.com \\ 4 Center of Excellence in Integrated Nano-Systems, King Abdulaziz City for Science and Technology, \\ P.O. Box 6086, Riyadh 11442, Saudi Arabia; mhhalotaibi@kacst.edu.sa \\ * Correspondence: gelhiti@ksu.edu.sa (G.A.E.-H.); emadayousif@gmail.com (E.Y.); \\ Tel.: +966-11469-3778 (G.A.E.-H.); Fax: +966-11469-3536 (G.A.E.-H.)
}

Received: 3 January 2018; Accepted: 25 January 2018; Published: 28 January 2018

\begin{abstract}
Three organotin(IV) complexes containing ciprofloxacin as a ligand $\left(\mathrm{Ph}_{3} \mathrm{SnL}, \mathrm{Me}_{2} \mathrm{SnL}_{2}\right.$ and $\mathrm{Bu}_{2} \mathrm{SnL}_{2} ; 0.5 \%$ by weight) were used as additives to inhibit the photodegradation of polyvinyl chloride films $\left(40 \mu \mathrm{m}\right.$ thickness) upon irradiation with ultraviolet light $\left(\lambda_{\max }=313\right.$ at a light intensity $=7.75 \times 10^{-7}$ ein $\mathrm{dm}^{-3} \mathrm{~S}^{-1}$ ) at room temperature. The efficiency of organotin(IV) complexes as photostabilizers was determined by monitoring the changes in the weight, growth of specific functional groups (hydroxyl, carbonyl and carbene), viscosity, average molecular weight, chain scission and degree of deterioration of the polymeric films upon irradiation. The results obtained indicated that organotin(IV) complexes stabilized poly(vinyl chloride) and the dimethyltin(IV) complex was the most efficient additive. The surface morphologies of poly(vinyl chloride) films containing organotin(IV) complexes were examined using an atomic force microscope and scanning electron microscopy. These showed that the surface of polymeric films containing organotin(IV) complexes were smoother and less rough, compared to the surface of the blank films. Some mechanisms that explained the role of organotin(IV) complexes in poly(vinyl chloride) photostabilization process were proposed.
\end{abstract}

Keywords: poly(vinyl chloride); photodegradation; ciprofloxacin; organotin(IV) complexes; ultraviolet irradiation; scanning electron microscope; atomic force microscope

\section{Introduction}

The market for poly(vinyl chloride) (PVC) has grown significantly over the years due low production cost and its large versatility [1-3]. However, environmental factors such as sunlight, ultraviolet (UV) radiation, moisture, and high temperatures can lead to various chemical and physical changes in the PVC materials [4-6]. Ultraviolet radiation has deleterious effects on PVC such as the scissions of the polymeric chains that lead to the loss of mechanical properties such as strength, elasticity, and color changes [7]. In addition, it can lead to the softening of polymeric materials, surface cracking, loss of transparency, bleaching, and surface erosion [8,9].

A UV light of a wavelength longer than 190-220 nm is not expected to be absorbed by PVC since it only contains single bonds (C-C, C-H, and C-Cl) [10]. Commercially available PVC has various 
structural defects due to the presence of several other molecules in small quantities [11]. The structural defects due to the presence of photosensitive chromophores such as allylic chlorine due to random unsaturation, tertiary bonded chloride, and impurities within the PVC polymeric chains can lead to photodegradation. In addition, the steric hindrance within the monomeric units, i.e., the tacticity, could influence the degradation process [9]. Therefore, the evaluation of the changes in the PVC properties under service conditions is very important in order to find ways to improve the durability of PVC containing products $[12,13]$. The susceptibility of PVC polymeric materials to UV light $(300-400 \mathrm{~nm})$ has been investigated [14-16]. Various additives at low concentrations have been used to inhibit the photodegradation process of PVC. The most common additives used are organometallics including organotin complexes [17-19], organics [20-22], Schiff bases [23-27], and others [28-33].

As a continuation of our research in the field of polymers [34-40], we began to investigate the effects of tin-ciprofloxacin complexes as additives at low concentrations ( $0.5 \%$ by weight) and their role in the inhibition of photodegradation of PVC films, upon irradiation with UV light for long period. We now report success in this respect in which the photostabilization effect of such additives was found to be better than the previously reported organotin complexes of leucine [17], 2-[(2,3-dihydroxyphenyl)methylideneamino]benzenesulfonic acid [18], and furosemide [19].

\section{Results and Discussions}

\subsection{Organotin(IV) Complexes}

Three organotin-ciprofloxacin complexes $\left(\mathrm{Ph}_{3} \mathrm{SnL}, \mathrm{Me}_{2} \mathrm{SnL}_{2}\right.$ and $\mathrm{Bu}_{2} \mathrm{SnL}_{2}$; Figure 1) were synthesized as previously reported [41] in 52-67\% yields and their colors range from white to pale yellow. The analytical and spectroscopic data for the synthesized complexes were consistent with the ones reported [41]. The synthesized organotin were varied in their structures in which diorganotin $\left(\mathrm{Me}_{2} \mathrm{SnL}_{2}\right.$ and $\left.\mathrm{Bu}_{2} \mathrm{SnL}_{2}\right)$ and triorganotin $\left(\mathrm{Ph}_{3} \mathrm{SnL}\right)$ were used. Also, the substituents on the Sn were varied as small $(\mathrm{Me})$ and bulky (Bu and $\mathrm{Ph}$ ) groups.

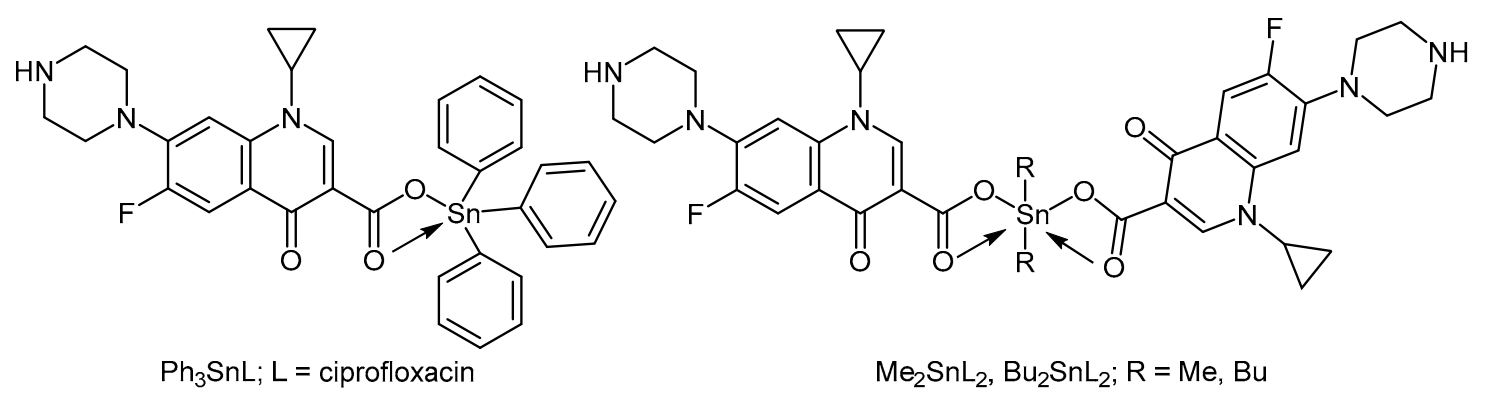

Figure 1. Organotin(IV)-ciprofloxacin complexes.

\subsection{Evaluation of PVC Photodegradation by Weight Loss}

Photodegradation of PVC produces low molecular weight fragments as well as hydrochloride $(\mathrm{HCl})$ that lead to a weight loss [42]. The weight loss of PVC films (40 $\mu \mathrm{m}$ thickness), in the presence of organotin(IV) complexes ( $0.5 \%$ by weight) upon irradiation $(300 \mathrm{~h})$, was calculated and compared to that obtained for the blank PVC film. Figure 2 shows the changes in the PVC weight loss percentage at different time of irradiation (up to $300 \mathrm{~h}$ ). Evidently, the PVC films containing organotin complexes show lower weight loss compared to that obtained for the blank PVC. Dimethyltin(IV) complex, $\mathrm{Me}_{2} \mathrm{SnL}_{2}$, shows the most efficient stabilization effect against PVC photodegradation. The dimethyltin(IV) complex is the least sterically hindered among the additives used and, therefore, it acts as a better primary photostabilizer compared to the others. Triphenyltin complex shows the least photostabilization effect presumably due to the presence of bulky phenyl groups. 


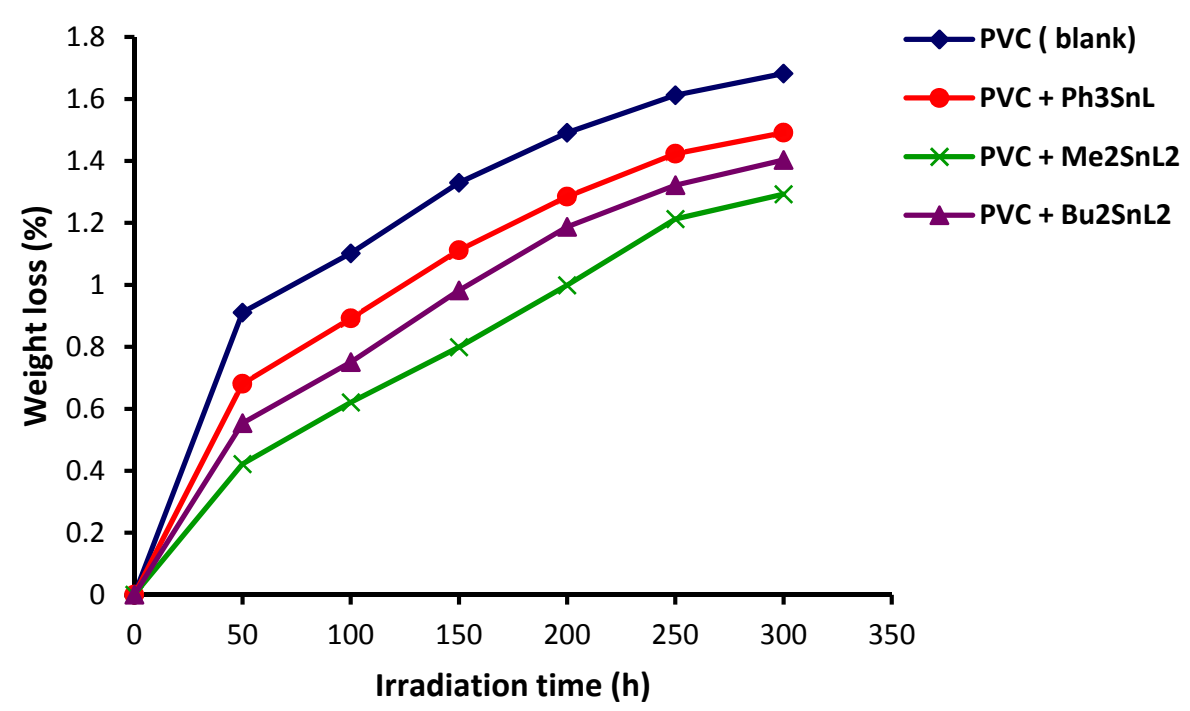

Figure 2. Changes in the weight loss (\%) of poly(vinyl chloride) (PVC) versus time of irradiation.

\subsection{Evaluation of PVC Photodegradation by FTIR Spectroscopy}

Ultraviolet radiation of PVC films leads to the appearance of several functional group moieties, in the IR spectra, such as $\mathrm{OH}\left(3500 \mathrm{~cm}^{-1}\right), \mathrm{C}=\mathrm{O}\left(1722 \mathrm{~cm}^{-1}\right)$ and $\mathrm{C}=\mathrm{C}\left(1602 \mathrm{~cm}^{-1}\right)$ [43]. The FTIR spectra of PVC films containing $\mathrm{Me}_{2} \mathrm{SnL}_{2}$ complex before and after irradiation $(300 \mathrm{~h})$ are shown in Figure 3.
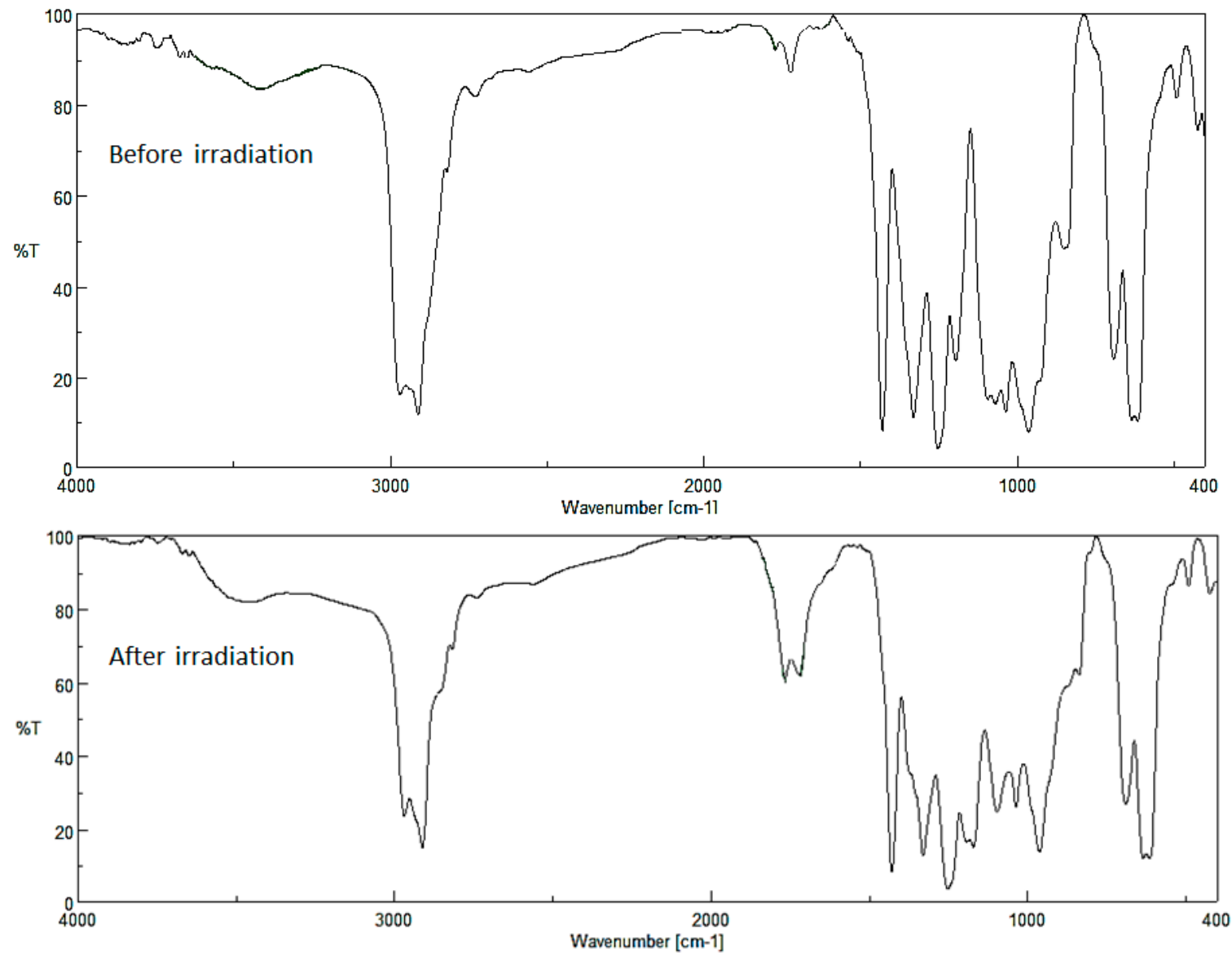

Figure 3. FTIR spectra of PVC film containing $\mathrm{Me}_{2} \mathrm{SnL}_{2}$ complex before and after irradiation. 
The intensities of $\mathrm{OH}, \mathrm{C}=\mathrm{O}$, and $\mathrm{C}=\mathrm{C}$ peaks in the FTIR spectra were monitored for irradiated PVC with a UV light $(\lambda \max =313 \mathrm{~nm})$ and compared to that obtained for the reference peak $\left(1328 \mathrm{~cm}^{-1}\right)$ [44]. The $I_{\mathrm{OH}}, I_{\mathrm{C}=\mathrm{O}}$, and $I_{\mathrm{C}=\mathrm{C}}$ indices were calculated for the PVC films in the presence and absence of organotin additives $(0.5 \%$ by weight) were calculated and plotted against time of irradiation (Figures 4-6). The $\mathrm{Me}_{2} \mathrm{SnL}_{2}$ complex was the most effective photostabilizer among the ones used for PVC photostabilization followed by the $\mathrm{Bu}_{2} \mathrm{SnL}_{2}$ and $\mathrm{Ph}_{3} \mathrm{SnL}$. The changes in the functional group indices were very noticeable for the blank PVC film compared to the ones containing organotin complexes. Clearly, such additives act as efficient photostabilizers to inhibit PVC photodegradation. Photo-oxidation of PVC leads mainly to chloroketone and ketone moieties along with alkene, hydroperoxide, and alcohol fragments [26]. Therefore, it was expected that the change in the $I_{\mathrm{C}=\mathrm{O}}$ (Figure 5) would be larger compared to the changes in $I_{\mathrm{C}=\mathrm{C}}$ (Figure 6).

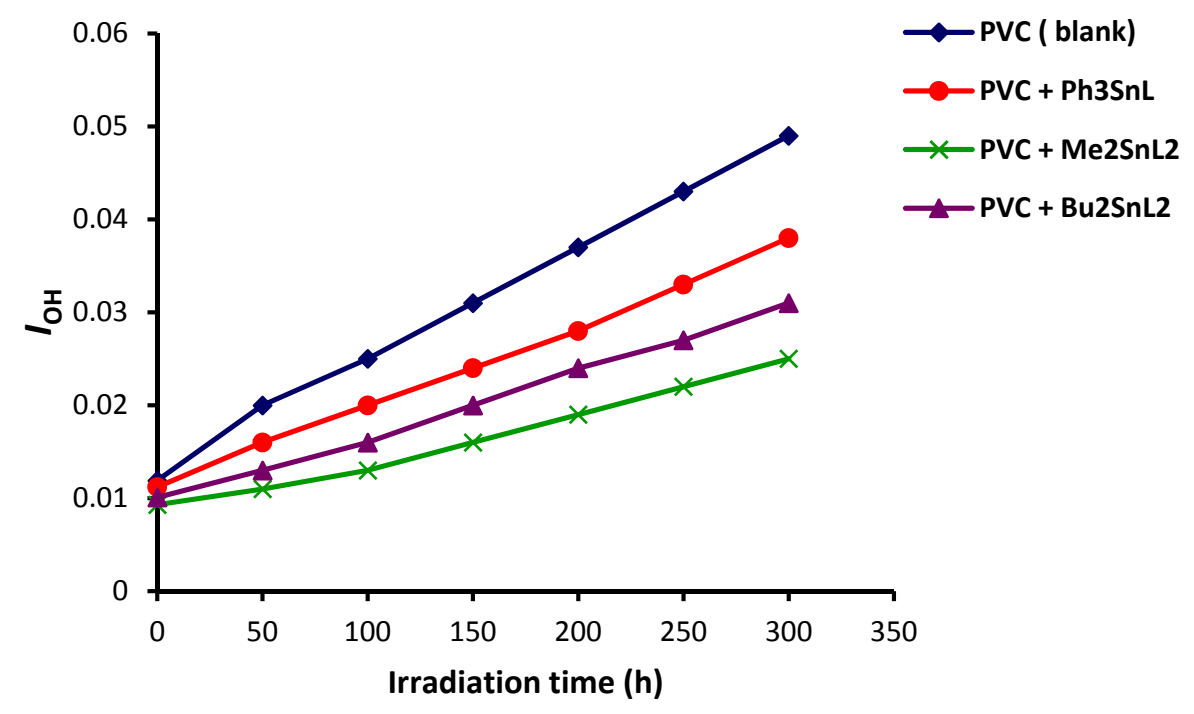

Figure 4. Changes in the $I_{\mathrm{OH}}$ index of PVC versus time of irradiation.

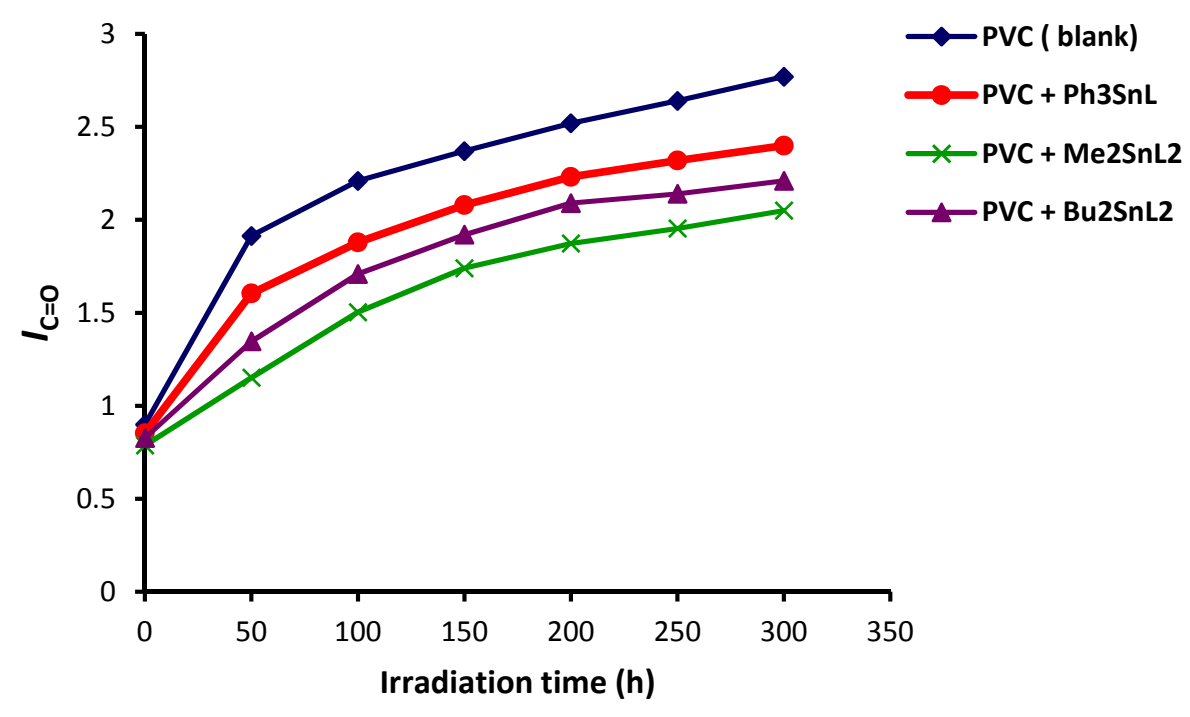

Figure 5. Changes in the $I_{\mathrm{C}=\mathrm{O}}$ index of PVC versus time of irradiation. 


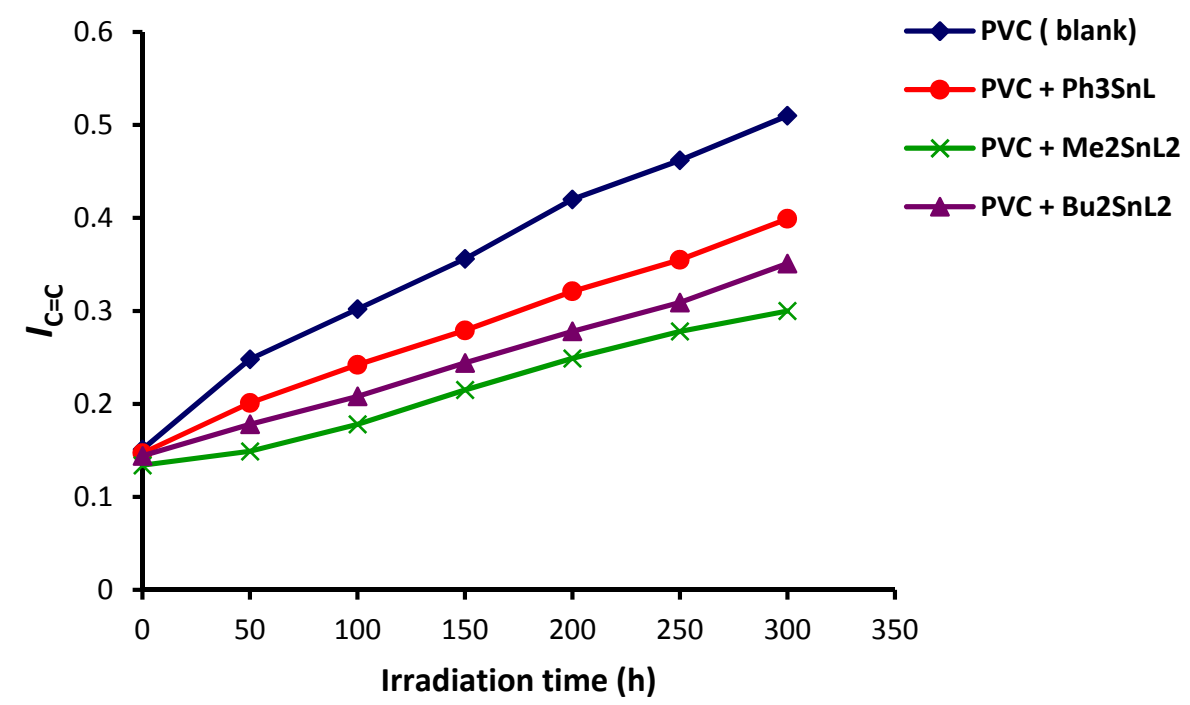

Figure 6. Changes in the $I_{\mathrm{C}=\mathrm{C}}$ index of PVC versus time of irradiation.

\subsection{Evaluation of PVC Photodegradation by Viscosity}

The exposure of PVC to UV light causes changes in the viscosity average molecular weight $\left(\bar{M}_{\mathrm{V}}\right)$ [45]. The $\bar{M}_{\mathrm{V}}$ for the PVC films upon irradiation was calculated at $25^{\circ} \mathrm{C}$ in THF. The relationship between time of irradiation (h) and the changes obtained in $\bar{M}_{\mathrm{V}}$ for PVC films (40 $\mu \mathrm{m}$ thickness) in the absence (blank) and presence of organotin(IV) complexes ( $0.5 \%$ by weight) was investigated (Figure 7). A sharp decrease in the $\bar{M}_{\mathrm{V}}$ was observed for PVC (blank) in comparison to the PVC containing organotin as additives up to $250 \mathrm{~h}$ of irradiation [46]. The decrease in $\bar{M}_{\mathrm{V}}$ was minimal for PVC containing $\mathrm{Me}_{2} \mathrm{SnL}_{2}$.
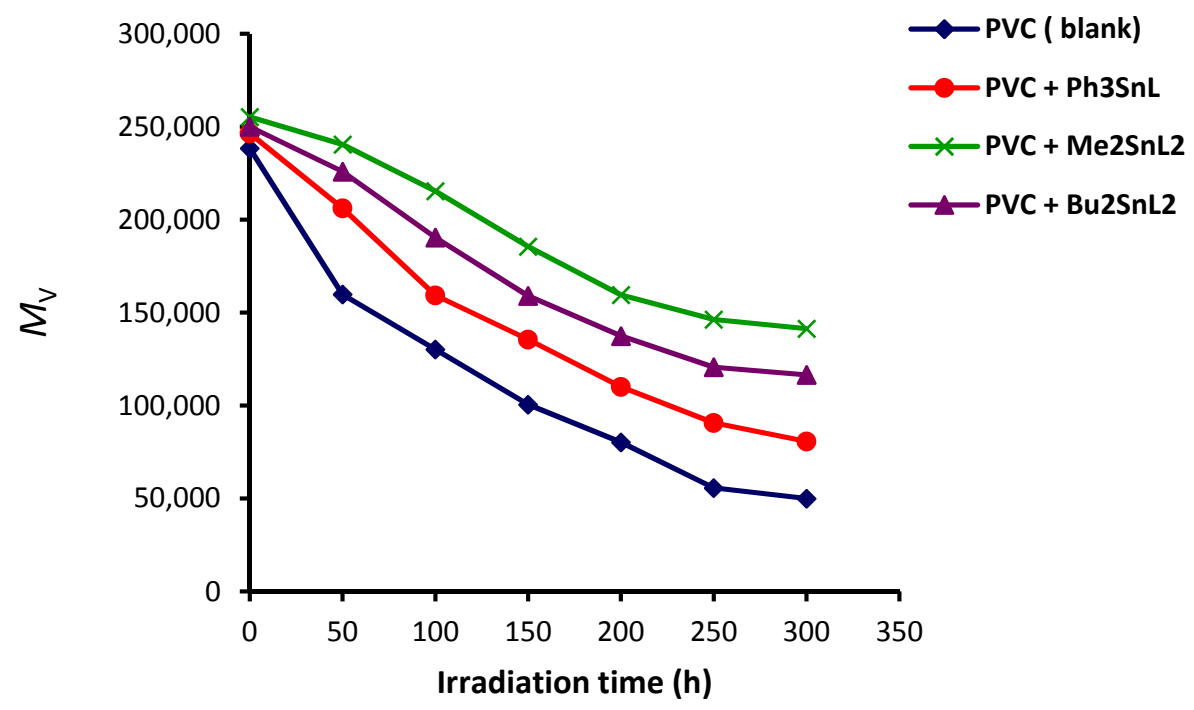

Figure 7. Changes in the $\bar{M}_{\mathrm{V}}$ of PVC versus time of irradiation.

Some insoluble residues in THF were seen during the PVC photolysis process. The quantity of such residues could be used as an indicator for the average chain scission $(S)$ due to the crosslinking and branching within the PVC polymeric chains [47]. Equation (1) can be used to calculate the $S$ value from the viscosity average molecular weight at the initial time of irradiation $\left(\bar{M}_{\mathrm{V}, \mathrm{O}}\right)$ and at $\mathrm{t}$ time of irradiation $\left(\bar{M}_{\mathrm{V}, \mathrm{t}}\right)$.

$$
\mathrm{S}=\bar{M}_{\mathrm{V}, \mathrm{O}} / \bar{M}_{\mathrm{V}, \mathrm{t}}-1
$$


The changes in the $S$ value for PVC films versus irradiation time (up to $300 \mathrm{~h}$ ) is shown in Figure 8. There was a sharp increase in the $S$ value for the blank PVC between an irradiation time of 100 and $300 \mathrm{~h}$. The growth of the $S$ value was less sharp for the PVC films that contain organotin(IV) complexes. Clearly, the additives used inhibit the photodegradation of PVC significantly. The increases in the $S$ value was minimal when dimethyltin complex was present.

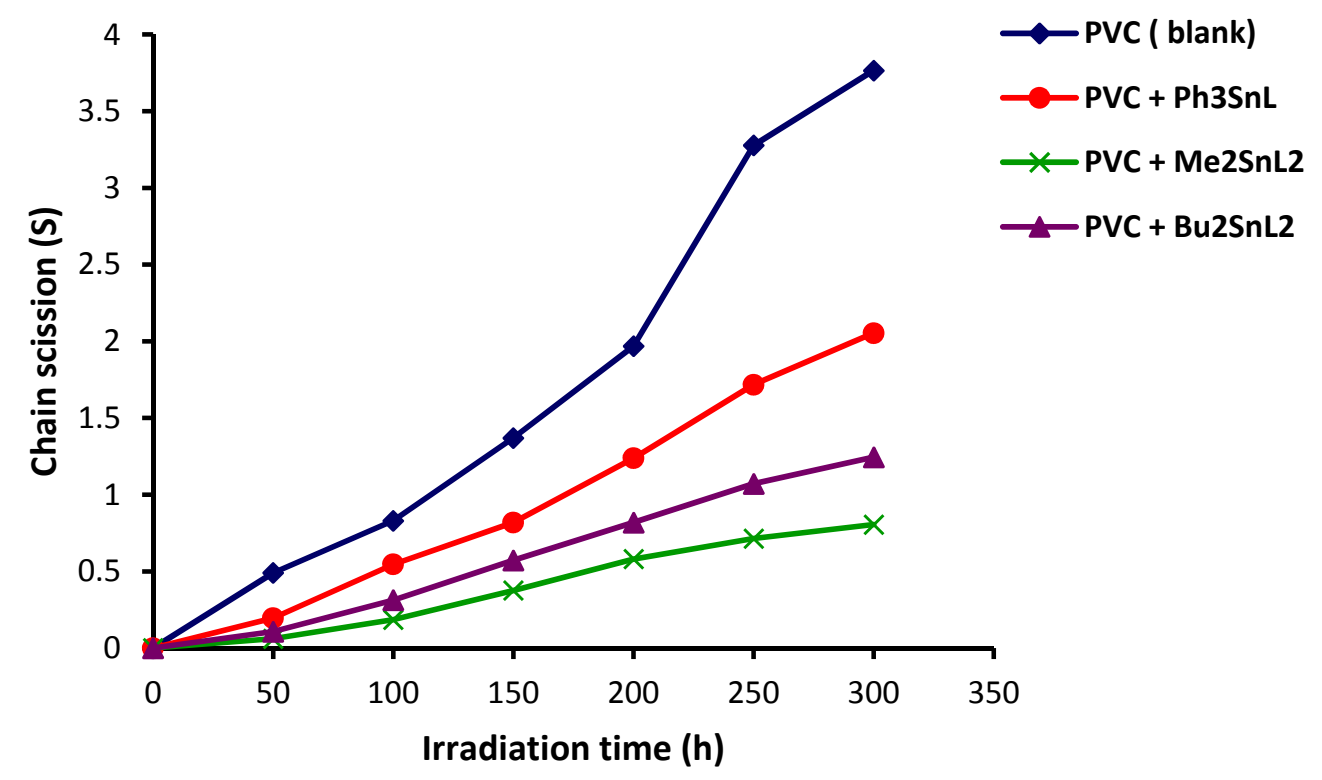

Figure 8. Changes in the chain scission $(S)$ of PVC versus time of irradiation.

At the initial stage of PVC photodegradation, randomly distributed weak bonds were rapidly broken. The degree of deterioration $(\alpha)$ which is a measure for PVC photodegradation can be calculated using Equation (2). The changes in the $\alpha$ values for PVC films containing photostabilizers on irradiation is represented in Figure 9.

$$
\alpha=m \cdot S / \bar{M}_{V}
$$

It can be seen that the $\alpha$ values for the irradiated PVC films containing organotin(IV) complexes were much less compared to the blank PVC. In the absence of additives, the $\alpha$ value increases with increasing time of irradiation. There was a sharp increase in the $\alpha$ values when the irradiation time increases from 150 to $300 \mathrm{~h}$. On the other hand, the $\alpha$ value was minimal when dimethyltin(IV) complex was used as additive.

\subsection{PVC Surface Morphological Study}

\subsubsection{Microscopic Analysis}

The morphological study for the PVC films provides a clear picture about the crystalline case, surface irregularity, smoothness, and roughness of the surface. In addition, it provides a tool to detect the changes take place within the PVC surface due to photodecomposition [48]. The PVC surface images before and after $300 \mathrm{~h}$ of irradiation are shown in Figure 10. 


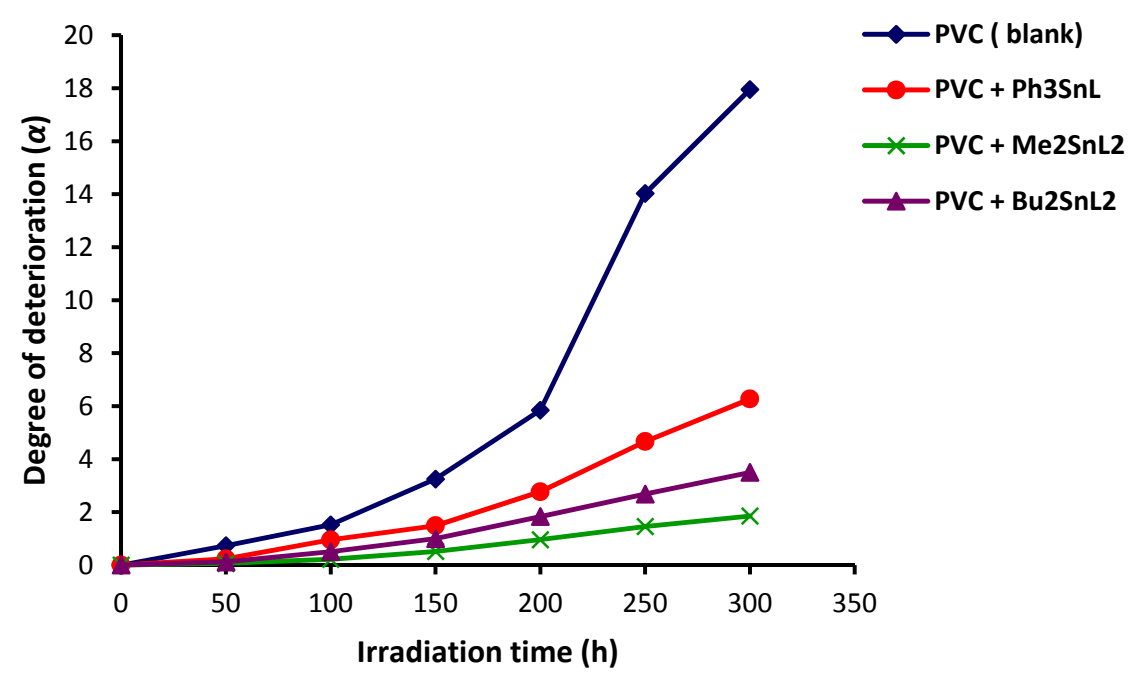

Figure 9. Changes in the degree of deterioration $(\alpha)$ of PVC versus time of irradiation.
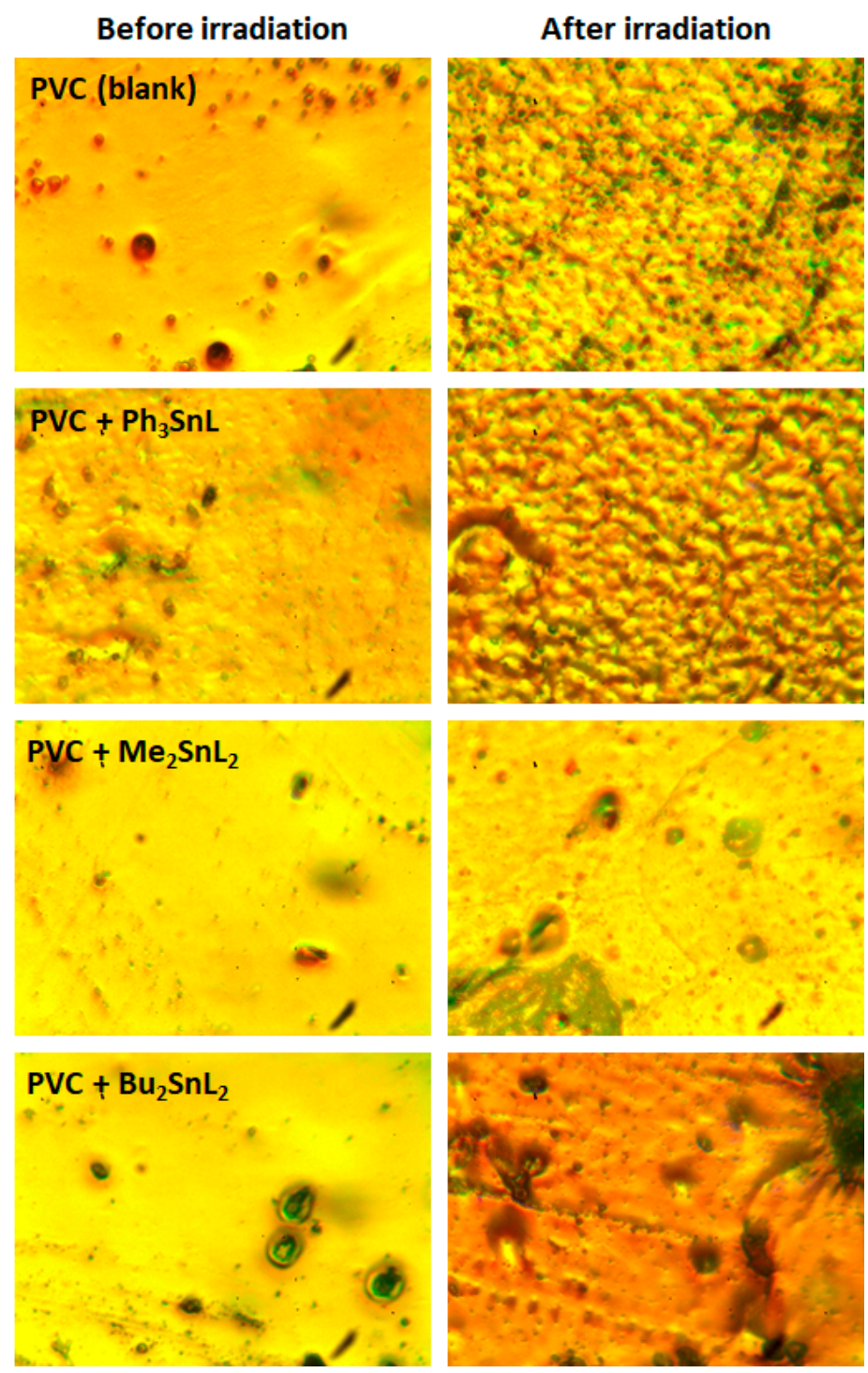

Figure 10. Microscope images of PVC films before and after irradiation. 
It can be seen that the PVC surface before irradiation were smooth with no white spots present. While, the PVC surface after irradiation has a degree of surface damage in which cracks, holes, and grooves as well as change in the color possibly were noticeable as a result of photodegradation and evolution of volatile products (e.g., dehydrochlorination). The images for the irradiated PVC films containing organotin(IV) complexes show less cracks and white spots. The PVC surface was much smoother with fewer numbers of cracks and white spots when $\mathrm{Me}_{2} \mathrm{SnL}_{2}$ complex was used as the additive.

\subsubsection{Scanning Electron Microscope (SEM) Analysis}

The SEM examines the effect of UV irradiation on the surface morphology of PVC films [49]. The SEM images of PVC films are shown in Figure 11. The surface of the blank PVC film before irradiation was essentially smooth and neat. The PVC surface was damaged after $300 \mathrm{~h}$ of irradiation and the damage was much noticeable for the blank PVC compared to the ones containing the organotin additives. Also, the cracks were larger in length and depth compared to the non-radiated film. The formation of such cracks can be due to the chain crosslinking and evaluation of $\mathrm{HCl}$ and other volatile degradation molecules [50]. It was clear that the PVC film containing $\mathrm{Me}_{2} \mathrm{SnL}_{2}$ complex exhibits the least surface roughness and damage.
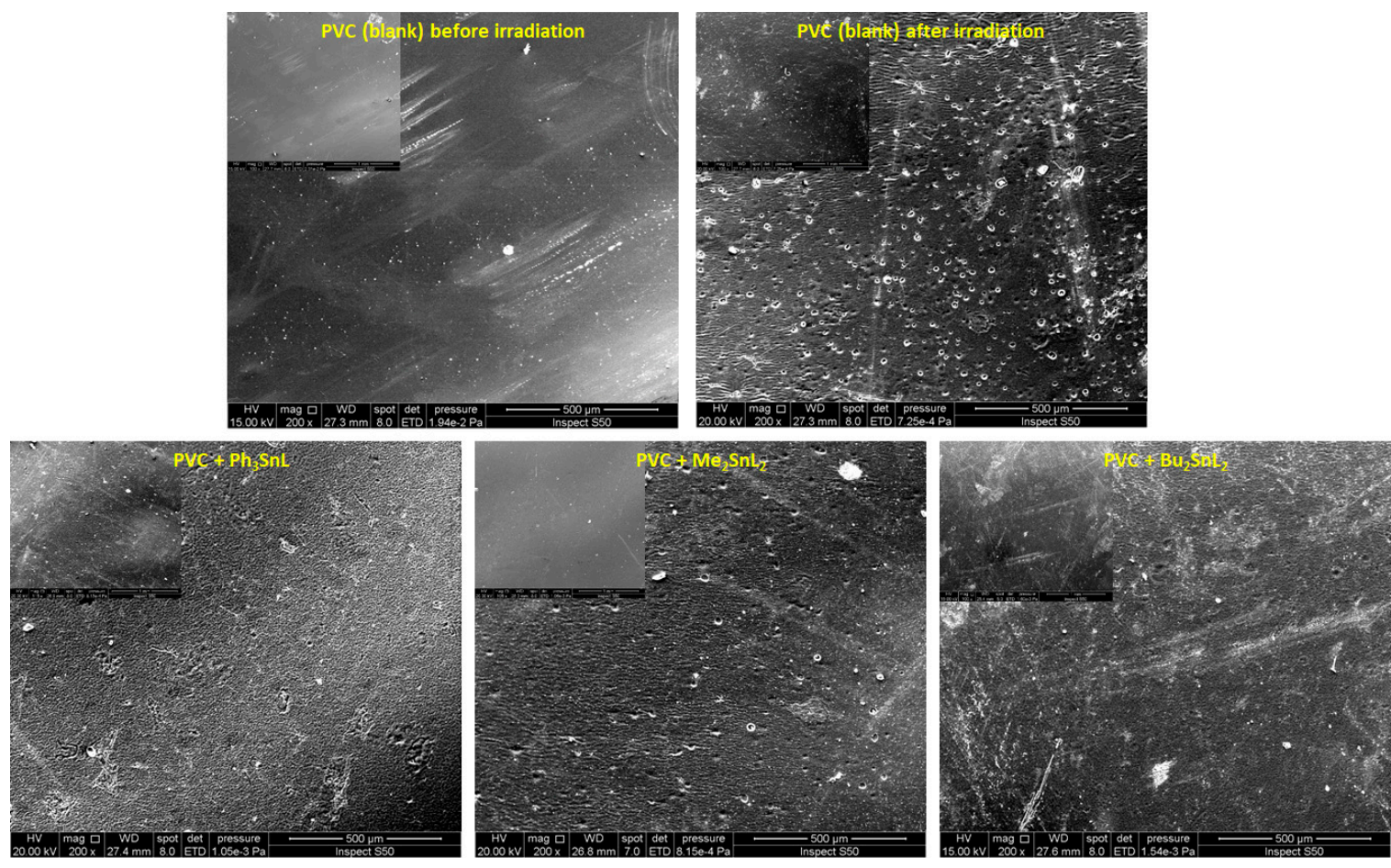

Figure 11. SEM images of PVC films.

\subsubsection{Atomic Force Microscopy (AFM) Analysis}

Atomic force microscopy (AFM) had been used to study the surface (area $=5.0 \times 5.0 \mu \mathrm{m}^{2}$ ) morphology of the PVC films after exposure to UV light for $300 \mathrm{~h}$. The AFM 2D and 3D images for PVC (blank) and the one containing $\mathrm{Me}_{2} \mathrm{SnL}_{2}$ complex, as a photostabilizer, after irradiation are shown in Figures 12 and 13, respectively. The PVC surface smoothness can be evaluated through the roughness factor $(R q)$ [51]. High $R q$ indicates dehydrochlorination and bond breaking that lead to rough surface [52,53]. Dehydrochlorination process normally takes place at high temperature [53]. The roughness factor was high $(\mathrm{Rq}=17.92)$ for the PVC (blank) compared to the one containing the 
$\mathrm{Me}_{2} \mathrm{SnL}_{2}$ complex $(\mathrm{Rq}=1.08)$ after $300 \mathrm{~h}$ of irradiation. Such result demonstrates the efficient use of dimethyltin complex to inhabit the PVC photodegradation.

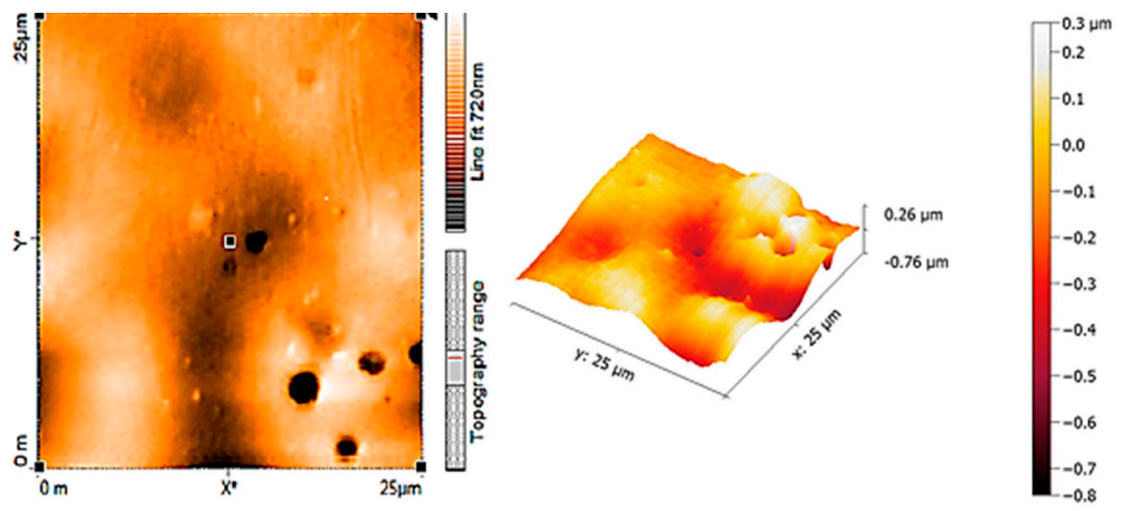

Figure 12. Atomic Force Microscopy (AFM) 2D and 3D images for PVC (blank) after irradiation.
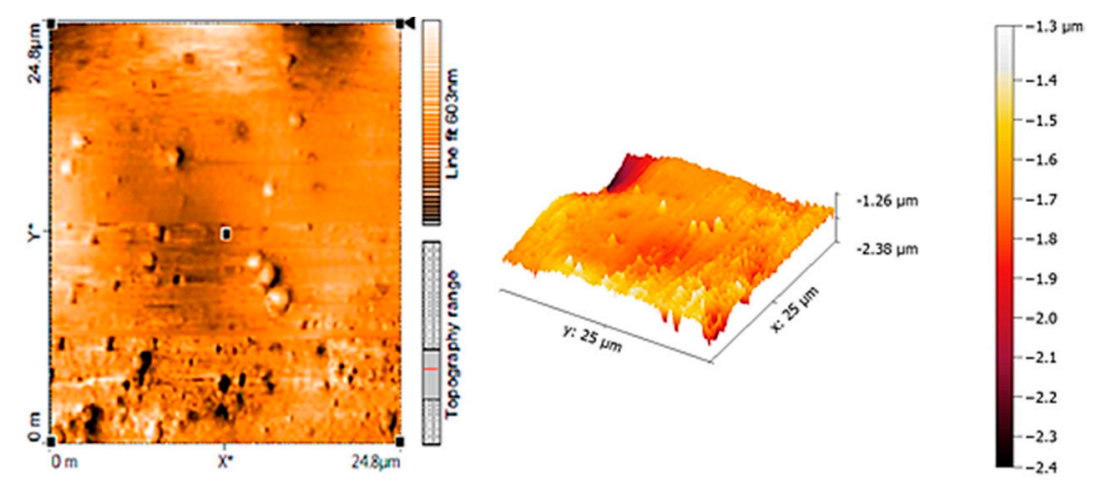

Figure 13. AFM $2 \mathrm{D}$ and $3 \mathrm{D}$ images for PVC containing $\mathrm{Me}_{2} \mathrm{SnL}_{2}$ after irradiation.

\subsection{Suggested Mechanisms for PVC Photostabilization by Organotin(IV) Complexes}

The efficiency of di- and triorganotin(IV) complexes as PVC photostabilizers follow the order $\mathrm{Me}_{2} \mathrm{SnL}_{2}>\mathrm{Bu}_{2} \mathrm{SnL}_{2}>\mathrm{Ph}_{3} \mathrm{SnL}$. The three organotin(IV) complexes used have reduced the PVC photodegradation significantly, but, the $\mathrm{Me}_{2} \mathrm{SnL}_{2}$ was the most effective one. Several mechanisms could be suggested to explain the photostabilization efficiency of these additives. Tin(IV) is a strong Lewis and, therefore, it acts as a good $\mathrm{HCl}$ scavenger (Scheme 1). Tin atoms can substitute the chlorine atoms within the PVC chains by the oxygen atoms of the carboxylate groups. Tin(IV) complexes can provide long-term PVC photostability by acting as secondary photostabilizers [29].<smiles>[R7][Sn]([R1])([R7])OC(=O)c1cn(C2CC2)c2cc(N3CCNCC3)c(F)cc2c1=O</smiles>

Scheme 1. Organotin(IV) complexes as $\mathrm{HCl}$ scavengers. 
The coordination between the polarized bonds within the organotin complexes and the $\mathrm{C}-\mathrm{Cl}$ bonds within polymeric chains could inhibits the PVC photodegradation (Scheme 2). Organotin complex could act as primary photostabilizers by absorbing the light energy. Also, they help to release the energy of the PVC exited state, over time, to an energy level that is harmless to the polymeric materials $[22,54]$. Clearly, the steric effect within triphenyltin complex render such additive to be an efficient primary stabilizer.

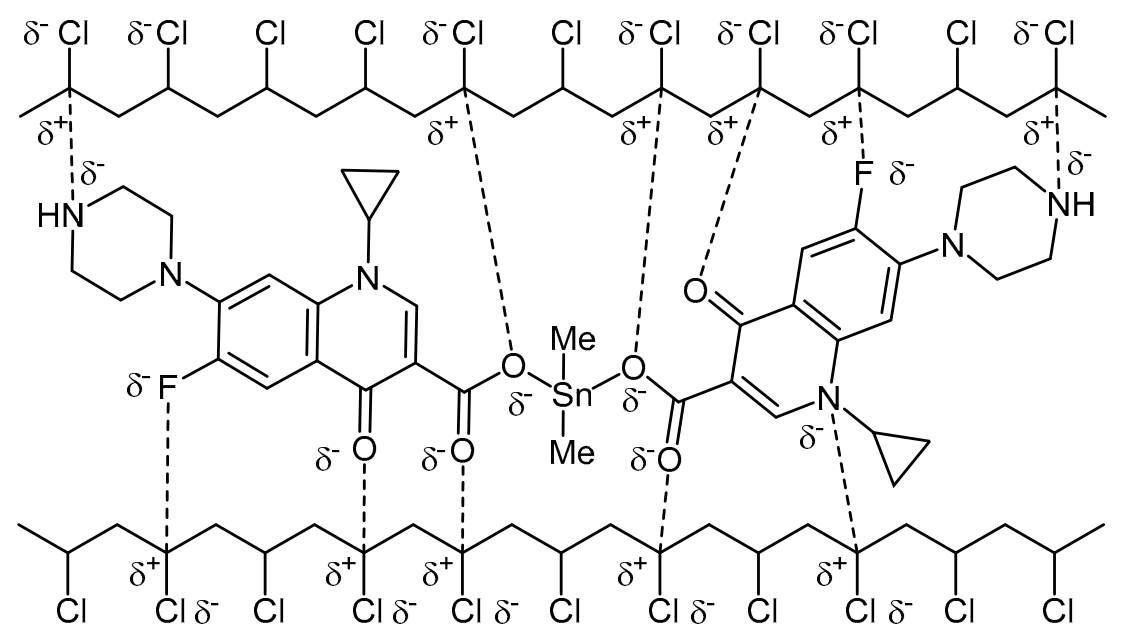

Scheme 2. Organotin(IV) complexes as primary stabilizers.

Organotin complexes could also act as peroxide decomposers to inhibit photodegradation of PVC. Photo-oxidation of PVC forms carbon radicals that lead to the production of peroxide radicals on reaction with oxygen [53]. Therefore, it is expected that tin complexes can decompose peroxides (e.g., hyrdroperoxides) and inhibit PVC photodegradation (Scheme 3) [55].

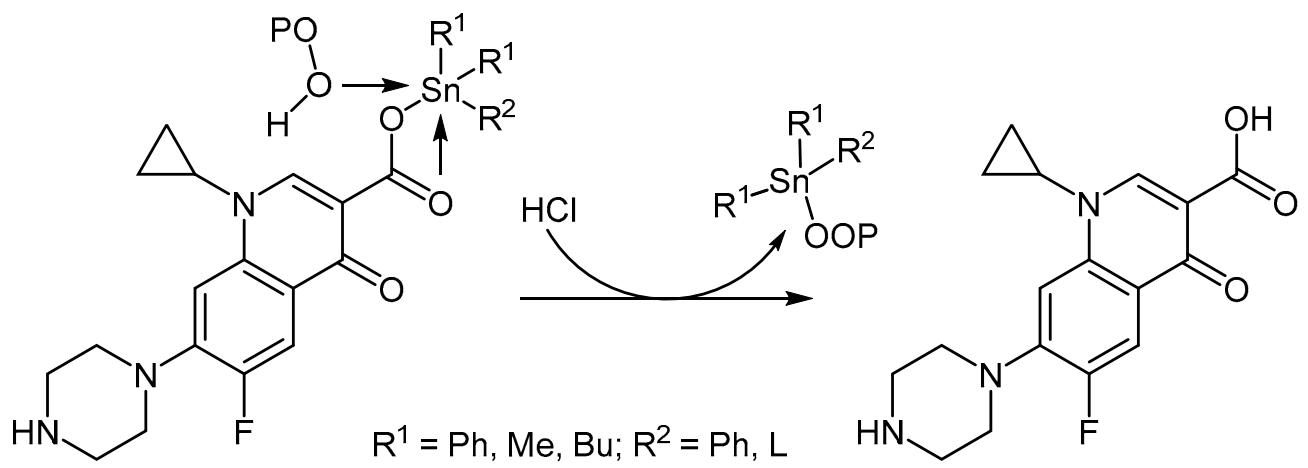

Scheme 3. Organotin(IV) complexes as peroxide decomposers.

Organotin(IV) complexes could inhibit PVC photodegradation by acting as radical scavengers (Scheme 4). Complexation could take place between the chromophore (e.g., peroxide radical; POO.) and the additives to form un-reactive charge transfer complexes [55]. Also, organotin(IV) complexes can absorb UV light directly and the energy absorbed can be dissipated at harmless level to the polymeric chains possibly due to the resonance within the aromatic moieties [22]. 
<smiles>[R17][R]([R17])([H])[H]</smiles>

Scheme 4. Organotin(IV) complexes as radical scavengers.

\section{Experimental}

\subsection{General}

Ciprofloxacin, reagents, and solvents were supplied from Sigma-Aldrich Chemical Company (Gillingham, UK). PVC (K-value $=67$, degree of polymerization $=800$ ) was purchased from Petkim Petrokimya (Istanbul, Turkey). The Fourier transform infrared (FTIR) spectra of PVC films were recorded using a FTIR-8300 Shimadzu Spectrophotometer (Kyoto, Japan) at $400-4000 \mathrm{~cm}^{-1}$ (KBr disc). An accelerated weather-meter QUV tester (Philips, Saarbrücken, Germany) equipped with UV-B 313 lamps $\left(\lambda_{\max }=313 \mathrm{~nm}\right.$ and light intensity $=7.75 \times 10^{-7}$ ein $\left.\mathrm{dm}^{-3} \mathrm{~s}^{-1}\right)$ was used to irradiate the PVC films $\left(25^{\circ} \mathrm{C}\right)$. The PVC surface morphology was inspected using Meiji Techno Microscope (Tokyo, Japan). The atomic force microscopy (AFM) images were recorded on Veeco instrument (Plainview, NY, USA). The scanning electron microscope (SEM) images of the PVC surface was recorded on the Veeco instrument (Veeco Instruments Inc., Plainview, New York, NY, USA) at an accelerating voltage of $15.00 \mathrm{kV}$.

\subsection{Synthesis of Organotin(IV) Complexes}

Triphenyltin(IV) complex containing ciprofloxacin (1-cyclopropyl-6-fluoro-4-oxo-7-piperazin-1ylquinoline-3-carboxylic acid) as a ligand (Figure 1) was synthesized as previously reported [41]. The reaction of equimolar ratio of ciprofloxacin $(\mathrm{L})$ and triphenyltin chloride $\left(\mathrm{Ph}_{3} \mathrm{SnCl}\right)$ in refluxing methanol for $6 \mathrm{~h}$ gave $\mathrm{Ph}_{3} \mathrm{SnL}$ complex as a white solid in $67 \%$. Similarly, the reaction of excess ciprofloxacin (two mole equivalents) and dimethyltin dichloride $\left(\mathrm{Me}_{2} \mathrm{SnCl}_{2}\right)$ or dibutyltin dichloride $\left(\mathrm{Bu}_{2} \mathrm{SnCl}_{2}\right)$, in ethanol under reflux for $8 \mathrm{~h}$, gave the corresponding $\mathrm{Bu}_{2} \mathrm{SnL}_{2}$ complex as a pale-yellow solid (52\%) or $\mathrm{Me}_{2} \mathrm{SnL}_{2}$ complex as an off white solid (61\%) [41].

\subsection{Preparation of PVC Films}

A solution of PVC (5 g) and organotin(IV) complexes (0.5\% by weight) in tetrahydrofuran (THF; $100 \mathrm{~mL}$ ) were stirred at $25^{\circ} \mathrm{C}$ for $30 \mathrm{~min}$. The mixture was casted onto glass plates and left at $25^{\circ} \mathrm{C}$ for $24 \mathrm{~h}$ to ensure evaporation of residual of THF and the produced films were fixed.

\subsection{Evaluation of PVC Photodegradation by Weight Loss}

The photostabilization potency of organotin(IV) complexes as additives was evaluated by measuring the weight loss percentage within PVC films during irradiation using Equation (3), where, $W_{1}$ and $W_{2}$ are the PVC weight before and after irradiation, respectively [55]. The PVC weight was measured using Sartorius Lab-BL $219 S$ electronic balance (Sartorius, Göttingen, Germany) with an accuracy of $0.0001 \mathrm{~g}$.

$$
\text { Weight loss } \%=\left[\left(W_{1}-W_{2}\right) / W_{1}\right] \times 100 \text {. }
$$




\subsection{Evaluation of PVC Photodegradation by FTIR Spectroscopy}

Photodegradation of PVC leads to the formation of a number of functional groups [56]. It has been reported that PVC photo-oxidation produces hydroxyl, carbonyl, and conjugated double bonds moieties $[10,57,58]$. The degree of photodegradation can be determined by monitoring the signals for such groups in the FTIR spectra $\left(400-4000 \mathrm{~cm}^{-1}\right)$ of PVC films upon irradiation. The changes in hydroxyl $\left(I_{\mathrm{OH}} ; 3500 \mathrm{~cm}^{-1}\right)$, carbonyl $\left(I_{\mathrm{C}=\mathrm{O}} ; 1722 \mathrm{~cm}^{-1}\right)$, and polyene $\left(I_{\mathrm{C}=\mathrm{C}} ; 1602 \mathrm{~cm}^{-1}\right)$ indices were calculated and compared to a reference peak $\left(1328 \mathrm{~cm}^{-1}\right)$ [44]. The reference peak is assigned to the scissoring and bending of the $\mathrm{CH}_{2}$ groups in the FTIR spectra for PVC. Equation (4) was used to calculate the functional group index $\left(I_{\mathrm{S}}\right)$ from the absorbance of the functional group $\left(A_{\mathrm{S}}\right)$ and the reference peak $\left(A_{\mathrm{r}}\right)$.

$$
I \mathrm{~s}=A \mathrm{~s} / A \mathrm{r} .
$$

\subsection{Evaluation of PVC Photodegradation by Viscosity}

Viscosity, [ $\eta$ ], can be used to evaluate the changes in PVC average molecular weight $\left(\bar{M}_{\mathrm{V}}^{\alpha}\right)$ using the Mark-Houwink relation shown in Equation (5), where, $\alpha$ and $K$ are constants [59].

$$
[\eta]=K \bar{M}_{\mathrm{V}}^{\alpha}
$$

The PVC molecular weight was calculated from the intrinsic viscosities using Equation (6).

$$
[\eta]=1.38 \times 10^{-4} \bar{M}_{\mathrm{V}}^{0.77}
$$

\section{Conclusions}

Three organotin(IV) complexes containing ciprofloxacin as a ligand have been used as photostabilizers to inhibit the photodegradation of PVC films, upon irradiation with ultraviolet light for a long period. Various methods such as the growth of certain functional groups in the infrared spectra, percentage of weight loss, variation in molecular weight, chain scission and degree of deterioration were used to determine the efficiency of organotin(IV) complexes. In addition, the atomic force and scanning electron microscopy were used to assess the surface morphology of poly(vinyl chloride) films. The organotin(IV) complexes used act as efficient photostabilizers and reduce the photodegradation rate of poly(vinyl chloride). It is believed that organotin(IV) complexes act as hydrogen chloride scavengers, peroxide decomposers, free radical scavengers and UV absorbers. For future research using organotin complexes as PVC photostabilizers, the possible leakage of tin should be assessed in order to allow the long-term use of such additives.

Acknowledgments: The project was supported by King Saud University, the Deanship of Scientific Research, Research Chairs.

Author Contributions: Gamal A. El-Hiti, Emad Yousif, and Mohammad Hayal Alotaibi conceived and designed the experiments. Duaa Ghazi performed the experiments and analyzed the data. Gamal A. El-Hiti, Emad Yousif and Dina S. Ahmed wrote the paper. All authors discussed the results and improved the final text of the paper.

Conflicts of Interest: The authors declare no conflict of interest.

\section{References}

1. $\quad$ Burgess, R.H. Manufacture and Processing of PVC; Applied Science Publishers: London, UK, 1982.

2. Wickson, E.J. Handbook of Polyvinyl Chloride Formulating; John Wiley and Sons: New York, NY, USA, 1993.

3. Patrick, S.G. Practical Guide to Polyvinyl Chloride; Rapra Technology Limited: Shrewsbury, UK, 2005.

4. Rabek, J.F. Comprehensive Chemical Kinetic; Degradation of Polymers; Bamford, C.H., Tipper, C.H.F., Eds.; Elsevier: Amsterdam, The Netherlands, 1975; Volume 1.

5. Grassie, N.; Scott, G. Polymer Degradation and Stabilisation; Cambridge University Press: Cambridge, UK, 1988.

6. Jellinek, H.H.G. Aspects of Degradation and Stabilization of Polymers; Elsevier: Amsterdam, The Netherlands, 1978. 
7. Ye, X.; Pi, H.; Guo, S. A novel route for preparation of PVC sheets with high UV irradiation resistance. J. Appl. Polym. Sci. 2010, 117, 2899-2906. [CrossRef]

8. Chaochanchaikul, K.; Rosarpitak, V.; Sombatsompop, N. Photodegradation profiles of PVC compound and wood/PVC composites under UV weathering. eXPRESS Polym. Lett. 2013, 7, 146-160. [CrossRef]

9. Decker, C.; Balandier, M. Photo-oxidation of poly(vinyl chloride). Polym. Photochem. 1981, 1, 221-232. [CrossRef]

10. Rabek, J.-F. Polymer Photodegradation: Mechanisms and Experimental Methods; Chapman \& Hall: London, UK, 1995.

11. Starnes, W.H. Structural defects in poly(vinyl chloride) and the mechanism of vinyl chloride polymerization: Comments on recent studies. Procedia Chem. 2012, 4, 1-10. [CrossRef]

12. Alizadeh, T.; Rashedi, M.; Hanifehpour, Y.; Joo, S.W. Improvement of durability and analytical characteristics of arsenic-imprinted polymer-based PVC membrane electrode via surface modification of nano-sized imprinted polymer particles: Part 2. Electrochim. Acta 2015, 178, 877-885. [CrossRef]

13. Grossman, R.F. Handbook of Vinyl Formulating, 2nd ed.; John Wiley \& Sons: Hoboken, NJ, USA, 1993.

14. Gumargalieva, K.Z.; Ivanov, V.B.; Zaikov, G.E.; Moiseev, Ju.V.; Pokholok, T.V. Problems of ageing and stabilization of poly(vinyl chloride). Polym. Degrad. Stab. 1996, 52, 73-79. [CrossRef]

15. Ahmed, N.M.; Mansour, S.H.; Abd-El-Messieh, S.L. Performance properties of pigmented polyvinyl chloride nanocomposites. Mater. Des. 2010, 31, 4312-4320. [CrossRef]

16. Clough, R.L.; Gillen, K.T. Radiation-thermal degradation of PE and PVC mechanism of synergism and dose rate effects. Radiat. Phys. Chem. 1981, 18, 661-669. [CrossRef]

17. Yousif, E.; Salimon, J.; Salih, N.; Jawad, A.; Win, Y.-F. New stabilizers for PVC based on some diorganotin(IV) complexes with bezamidoleucine. Arab. J. Chem. 2016, 9, S1394-S1401. [CrossRef]

18. Martins, L.M.D.R.S.; Hazra, S.; Guedes de Silva, M.F.C.; Pombeiro, A.J.L. A sulfonated Schiff base dimethyltin(IV) coordination polymer: Synthesis, characterization and application as a catalyst for ultrasound- or microwave-assisted Baeyer-Villiger oxidation under solvent-free conditions. RSC Adv. 2016, 6, 78225-78233. [CrossRef]

19. Ali, M.M.; El-Hiti, G.A.; Yousif, E. Photostabilizng efficiency of poly(vinyl chloride) in the presence of organotin(IV) complexes as photostabilizers. Molecules 2016, 21, 1151. [CrossRef] [PubMed]

20. Sabaa, M.W.; Oraby, E.H.; Abdel Naby, A.S.; Mohammed, R.R. Anthraquinone derivatives as organic stabilizers for rigid poly(vinyl chloride) against photo-degradation. Eur. Polym. J. 2005, 41, 2530-2543. [CrossRef]

21. Sabaa, M.W.; Mikhael, M.G.; Mohamed, N.A.; Yassin, A.A. N-substituted maleimides as thermal stabilizers for rigid poly (vinyl chloride). Angew. Makromol. Chem. 1989, 168, 23-25. [CrossRef]

22. Balakit, A.A.; Ahmed, A.; El-Hiti, G.A.; Smith, K.; Yousif, E. Synthesis of new thiophene derivatives and their use as photostabilizers for rigid poly(vinyl chloride). Int. J. Polym. Sci. 2015, 2015, 510390. [CrossRef]

23. Yousif, E.; Hasan, A.; El-Hiti, G.A. Spectroscopic, physical and topography of photochemical process of PVC films in the presence of Schiff base metal complexes. Polymers 2016, 8, 204. [CrossRef]

24. Ali, G.Q.; El-Hiti, G.A.; Tomi, I.H.R.; Haddad, R.; Al-Qaisi, A.J.; Yousif, E. Photostability and performance of polystyrene films containing 1,2,4-triazole-3-thiol ring system Schiff bases. Molecules 2016, $21,1699$. [CrossRef] [PubMed]

25. Yousif, E.; Bakir, E.; Salimon, J.; Salih, N. Evaluation of Schiff bases of 2,5-dimercapto-1,3,4-thiadiazole as photostabilizer for poly(methyl methacrylate). J. Saudi Chem. Soc. 2012, 16, 279-285. [CrossRef]

26. Yousif, E.; El-Hiti, G.A.; Hussain, Z.; Altaie, A. Viscoelastic, spectroscopic and microscopic study of the photo irradiation effect on the stability of PVC in the presence of sulfamethoxazole Schiff's bases. Polymers 2015, 7, 2190-2204. [CrossRef]

27. Ahmed, D.S.; El-Hiti, G.A.; Hameed, A.S.; Yousif, E.; Ahmed, A. New tetra-Schiff bases as efficient photostabilizers for poly(vinyl chloride). Molecules 2017, 22, 1506. [CrossRef] [PubMed]

28. Mohammed, R.; El-Hiti, G.A.; Ahmed, A.; Yousif, E. Poly(vinyl chloride) doped by 2-(4-isobutylphenyl) propanoate metal complexes: enhanced resistance to UV irradiation. Arab. J. Sci. Eng. 2017, 42, 4307-4315. [CrossRef]

29. Folarin, O.M.; Sadiku, E.R. Thermal stabilizers for poly(vinyl chloride): A review. Int. J. Phys. Sci. 2011, 6, 4323-4330.

30. Deanin, R.D.; Reynolds, H.H.; Ozcayir, Y. Thermal stabilization of polyvinyl chloride by group II metal laurates. J. Appl. Polym. Sci. 1969, 13, 1247-1252. [CrossRef] 
31. Chen, X.; Li, C.; Zhang, L.; Xu, S.; Zhou, Q.; Zhu, Y.; Qu, X. Main factors in preparation of antibacterial particles /PVC composite. China Particuol. 2004, 2, 226-229. [CrossRef]

32. Cheng, Q.; Li, C.; Pavlinek, V.; Saha, P.; Wang, H. Surface-modified antibacterial $\mathrm{TiO}_{2} / \mathrm{Ag}^{+}$nanoparticles: Preparation and properties. Appl. Surf. Sci. 2006, 252, 4154-4160. [CrossRef]

33. Birmingham, J.N. The effect of surface oxidation and titanium dioxide on exterior PVC color retention. J. Vinyl Addit. Technol. 1995, 1, 84-87. [CrossRef]

34. Smith, K.; Balakit, A.A.; Pardasani, R.T.; El-Hiti, G.A. New polymeric sulfide-borane complexes: Convenient hydroborating and reducing reagents. J. Sulfur Chem. 2011, 32, 287-295. [CrossRef]

35. Smith, K.; Balakit, A.A.; El-Hiti, G.A. Poly(propylene sulfide)-borane: Convenient and versatile reagent for organic synthesis. Tetrahedron 2012, 68, 7834-7839. [CrossRef]

36. Yousif, E.; El-Hiti, G.A.; Haddad, R.; Balakit, A.A. Photochemical stability and photostabilizing efficiency of poly(methyl methacrylate) based on 2-(6-methoxynaphthalen-2-yl) propanoate metal ion complexes. Polymers 2015, 7, 1005-1019. [CrossRef]

37. Smith, K.; Al-Zuhairi, A.J.; El-Hiti, G.A.; Alshammari, M.B. Comparison of cyclic and polymeric disulfides as catalysts for the regioselective chlorination of phenols. J. Sulfur Chem. 2015, 36, 74-85. [CrossRef]

38. Altaee, N.; El-Hiti, G.A.; Fahdil, A.; Sudesh, K.; Yousif, E. Biodegradation of different formulations of polyhydroxybutyrate films in soil. SpringerPlus 2016, 5, 762. [CrossRef] [PubMed]

39. Altaee, N.; El-Hiti, G.A.; Fahdil, A.; Sudesh, K.; Yousif, E. Screening and evaluation of poly(3-hydroxybutyrate) with Rhodococcus. equi using different carbon sources. Arab. J. Sci. Eng. 2017, 42, 2371-2379. [CrossRef]

40. Ahmed, D.S.; El-Hiti, G.A.; Yousif, E.; Hameed, A.S.; Abdalla, M. New eco-friendly phosphorus organic polymers as gas storage media. Polymers 2017, 9, 336. [CrossRef]

41. Ghazi, D.; Yousif, E. Design of organotin (IV) complexes derived from ciprofloxacin. Int. J. Res. Eng. Innov. 2017, 1, 63-65.

42. Jafari, A.J.; Donaldson, J.D. Determination of $\mathrm{HCl}$ and VOC emission from thermal degradation of PVC in the absence and presence of copper, copper(II) Oxide and copper(II) chloride. Eur. J. Chem. 2009, 6, 685-692. [CrossRef]

43. Yassin, A.A.; Sabaa, M.W. Degradation and stabilization of poly(vinyl chloride). J. Macromol. Sci. Part C Polym. Rev. 1990, 30, 491-558. [CrossRef]

44. Gaumet, S.; Gardette, J.-L. Photo-oxidation of poly(vinyl chloride): Part 2-A comparative study of the carbonylated products in photo-chemical and thermal oxidations. Polym. Degrad. Stab. 1991, 33, 17-34. [CrossRef]

45. Cooray, B.; Scott, G. The effect of thermal processing on PVC-VI. The role of hydrogen chloride. Eur. Polym. J. 1980, 16, 169-177. [CrossRef]

46. Braun, D.; Rabie, S.T.; Khaireldin, N.Y.; Abd El-Ghaffar, M.A. Preparation and evaluation of some benzophenone terpolymers as photostabilizers for rigid PVC. J. Vinyl Addit. Technol. 2011, 17, 147-155. [CrossRef]

47. Allcock, H.; Lampe, F.; Mark, J.E. Contemporary Polymer Chemistry, 3rd ed.; Pearson Prentice-Hall: Upper Saddle River, New Jersey, NJ, USA, 2003.

48. Awaja, F.; Zhang, S.; Tripathi, M.; Nikiforov, A.; Pugno, N. Cracks, microcracks and fracture in polymer structures: Formation, detection, autonomic repair. Prog. Mater. Sci. 2016, 83, 536-573. [CrossRef]

49. Nikafshar, S.; Zabihi, O.; Ahmadi, M.; Mirmohseni, A.; Taseidifar, M.; Naebe, M. The effect of UV light on the chemical and mechanical properties of a transparent epoxy-diamine system in the presence of an organic UV absorber. Materials 2017, 10, 180. [CrossRef] [PubMed]

50. Shi, W.; Zhang, J.; Shi, X.-M.; Jiang, G.-D. Different photodegradation processes of PVC with different average degrees of polymerization. J. Appl. Polym. Sci. 2008, 107, 528-540. [CrossRef]

51. Kara, F.; Akosy, E.; Yuksekdaged, Z.; Hasirci, N.; Aksoy, S. Synthesis and surface modification of polyurethanes with chitosan for antibacterial properties. Carbohydr. Polym. 2014, 112, 39-47. [CrossRef] [PubMed]

52. Zheng, X.-G.; Tang, L.-H.; Zhang, N.; Gao, Q.-H.; Zhang, C.-F.; Zhu, Z.-B. Dehydrochlorination of PVC materials at high temperature. Energy Fuels 2003, 17, 896-900. [CrossRef]

53. Pospíšil, J.; Klemchuk, P.P. Oxidation Inhibition in Organic Materials; CRC Press: Boca Raton, FL, USA, 1989; pp. $48-49$. 
54. Li, D.; Zhou, M.; Xie, L.; Yu, X.; Yu, Y.; Ai, H.; Tang, S. Synergism of pentaerythritol-zinc with $\beta$-diketone and calcium stearate in poly(vinyl chloride) thermal stability. Polym. J. 2013, 45, 775-782. [CrossRef]

55. Sabaa, M.W.; Oraby, E.H.; Abdul Naby, A.S.; Mohamed, R.R. N-Phenyl-3-substituted-5-pyrazolone derivatives as organic stabilizer for rigid PVC against photodegradation. J. Appl. Polym. Sci. 2005, 101, 1543-1555. [CrossRef]

56. González, A.; Pastor, J.; De Saja, J.A. Monitoring the UV degradation of PVC window frames by micro hardness analysis. J. Appl. Polym. Sci. 1989, 38, 1879-1882. [CrossRef]

57. Mori, F.; Koyama, M.; Oki, Y. Studies on photodegradation of poly(vinyl chloride), part 3. Macromol. Mater. Eng. 1979, 75, 113-122. [CrossRef]

58. Kwei, K.-P.S. Photo-oxidation of poly(vinyl chloride). J. Polym. Sci. A 1969, 7, 1075-1088. [CrossRef]

59. Mark, J.E. Physical Properties of Polymers Handbook; Springer: New York, NY, USA, 2007.

Sample Availability: Samples of the organotin(IV) complexes are available from the authors.

(C) 2018 by the authors. Licensee MDPI, Basel, Switzerland. This article is an open access article distributed under the terms and conditions of the Creative Commons Attribution (CC BY) license (http://creativecommons.org/licenses/by/4.0/). 